\title{
ICE-MARGINAL DEPOSITIONAL PROCESSES IN A POLAR MARITIME ENVIRONMENT, VESTFOLD HILLS, ANTARCTICA
}

\author{
By SEAN J. FITZSIMONS
}

(Department of Geography and Oceanography, Australian Defence Force Academy,

University of New South Wales, Campbell, ACT 2601, Australia)

ABSTRACT. This study investigates the processes of icemarginal sedimentation in Vestfold Hills, Antarctica. Most debris is released from the ice when basal and englacial debris bands become warped and reach the surface of the glacier and where the debris bands are exposed by ablation of the ice surface. Once released, the debris is redistributed in the ice-marginal area by depositional processes that are controlled by the availability of water. During the short summer, melt water from snow and ice saturates the newly released debris and causes sediment flows and other mass-movement deposits. Melt-out and sublimation tills form after the layer of debris on the moraines is consolidated and melting rates decrease. When the thickness of deposits on the surface of ice-cored moraines reaches or exceeds the depth of summer thawing, the ice core no longer melts and the moraines become semi-permanent features. The sediments and land forms of the ice-marginal area closely resemble those formed by sub-polar glaciers with a complex thermal regime and are unlike those that form at the margins of dry-based polar glaciers. Although glacier thermal regime is understood to be a major control on debris dispersal and processes of glacial sedimentation, the evidence from Vestfold Hills suggests that the primary control is the climate of the glacier terminus area.

\section{INTRODUCTION}

The main controls on the nature and location of glacial deposition are glacier mass balance, thermal regime, bed configuration, the properties of the material being deposited, and the climate near the ice margin (Andrews, 1975; Lawson, 1979). Recent studies of glacial deposits forming at the margin of glaciers have stressed the role of thermal regime in determining the processes involved in their deposition (Boulton, 1972, 1975, 1976). From such studies, three thermal or glacio-dynamic basal regimes can be identified at modern ice margins (Eyles and others, 1983). Each of these thermal regimes has been associated with a diagnostic land form and sediment association (Boulton, 1976; Boulton and Paul, 1976; Eyles and others, 1983). The primary purpose of this study was to determine the nature of the deposits and land forms that form in Vestfold Hills and to establish whether they constitute a land form and sediment association similar to those known from sub-polar glaciers or glaciers in polar arid areas. Although the climate of Vestfold Hills appears to be intermediate between polar continental and sub-polar maritime climates, analysis of the depositonal processes has shown that the depositional system closely resembles that of sub-polar maritime climates and is quite unlike that of polar continental climates. It is concluded that, while the role of thermal regime in controlling the nature and location of glacial deposition has been emphasized in the literature, the evidence from Vestfold Hills suggests that the climate of the ice-terminus area is a more significant control on the nature of depositional processes.

\section{THE STUDY AREA}

Vestfold Hills are a small ice-free area in Princess Elizabeth Land, Antarctica (Fig. 1). The edge of the continental ice sheet runs from north to south and the southern limit of the ice-free area is formed by Sorsdal Glacier, which is the major outlet glacier of the area and forms a small ice shelf (Fig. 1). The hills consist of a complex low-relief topography composed of valleys at and below sea-level and ridges up to $158 \mathrm{~m}$ in altitude. Glacial sediments and land forms are absent from most of the ice-free area. They are concentrated in ice-marginal areas where most moraines are ice-

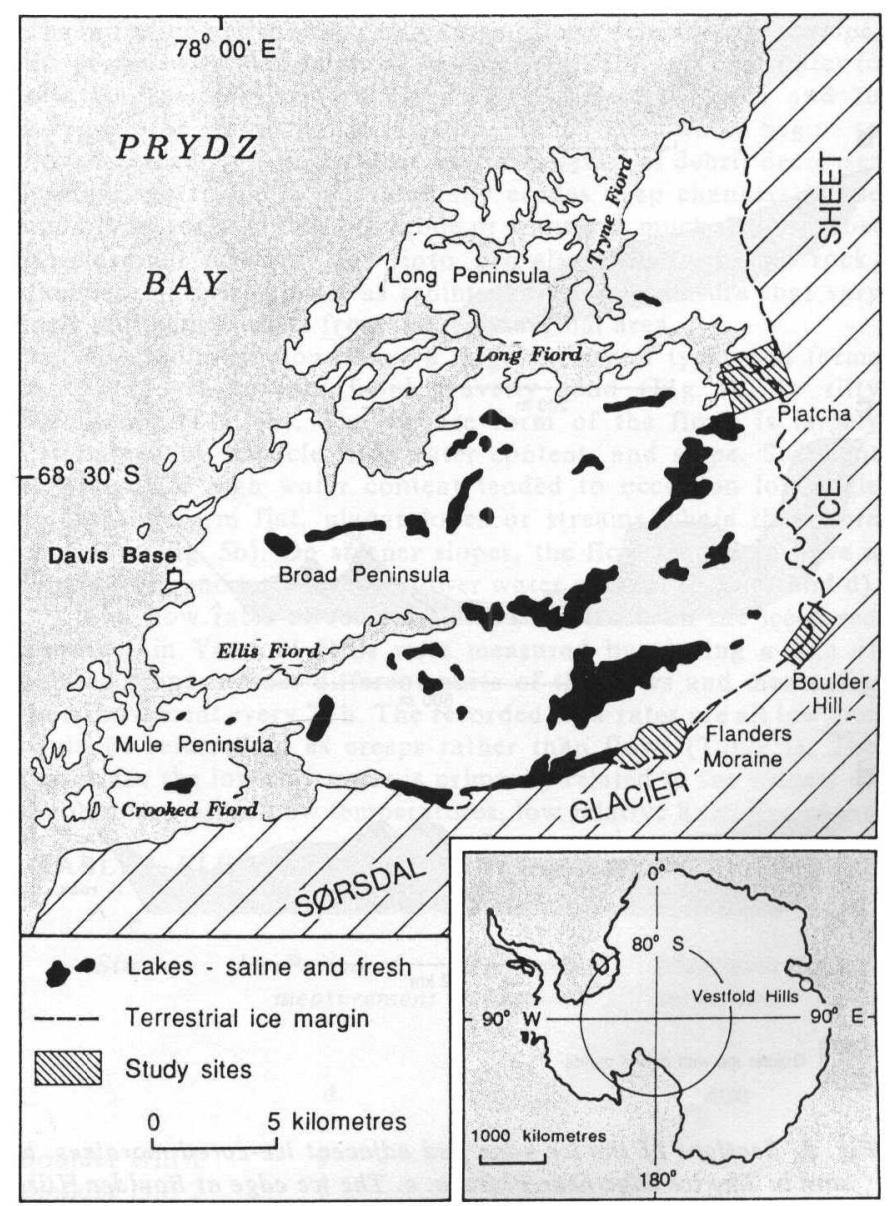

Fig. 1. Location map of Vestfold Hills showing the position of the edge of the continental ice sheet, Sarsdal Glacier, and the position of the three localities examined in detail. 
cored and appear to remain attached to the ice sheet.

The mean annual temperature of Vestfold Hills is $-10^{\circ} \mathrm{C}$ (Schwerdtfeger, 1970) which is, on average, warmer than Antarctic stations of similar latitude (Burton and Campbell, 1980). Although there are no precipitation data, rainfall has been observed and snowfall is light (probably $<250 \mathrm{mmyear}^{-1}$ ). The climate of Vestfold Hills restricts the melting of snow and ice to the short

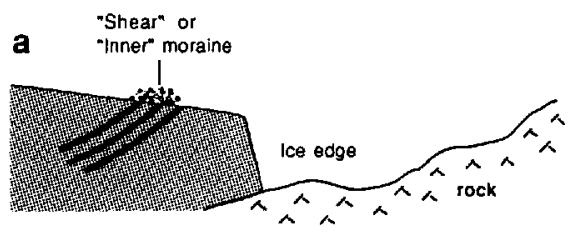

b

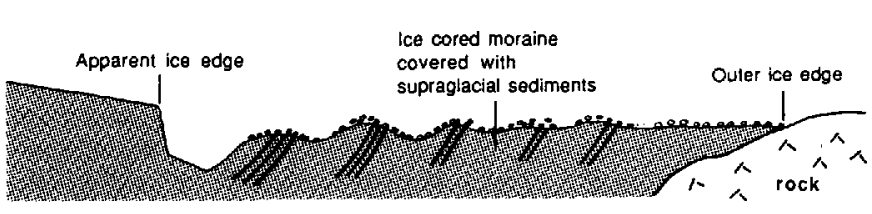

Glacier ice with debris bands

Fig. 2. Definitions of ice-marginal features at Vestfold Hills. a. Simple ice margin. b. Complex ice margin and ice-cored moraine.

a
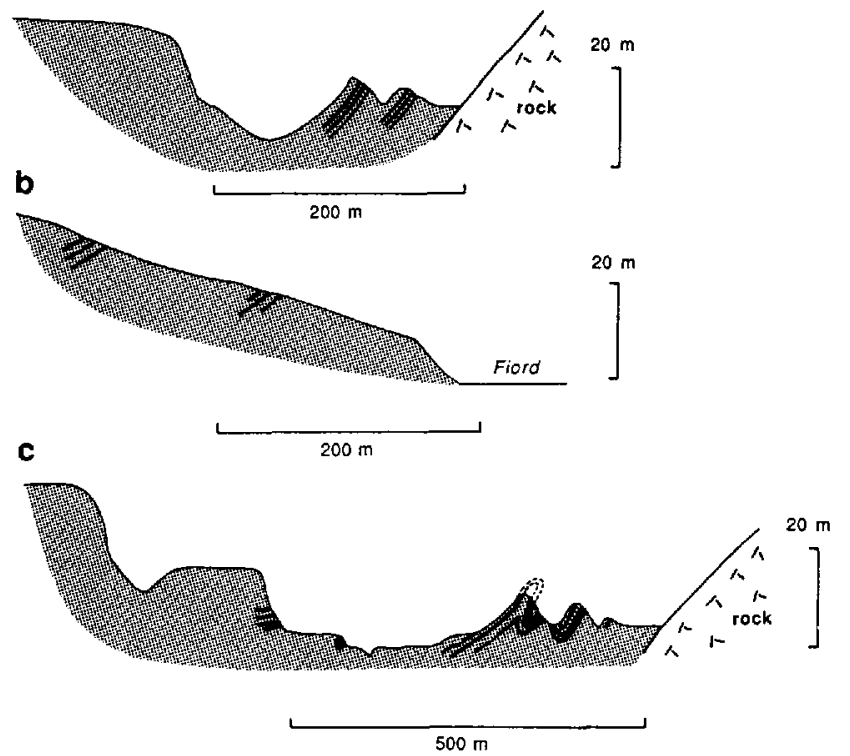

d

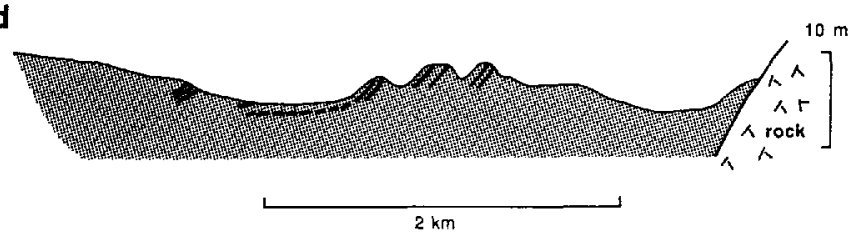

Glacier ice with debris bands

Fig. 3. Sections of the ice edge and adjacent ice-cored moraines. a and $b$. The ice edge near Platcha. $c$. The ice edge at Boulder Hill. d. The ice edge at Flanders Moraine. The profiles were surveyed with a level and the dip of the debris bands, though based on surface observations, is hypothetical. The areas where the profiles were surveyed are shown on Figure 1. summer (December-February). There is a strong diurnal component to the melt activity which usually ceases between 21.00 and $10.00 \mathrm{~h}$, when air temperatures are below or close to $0^{\circ} \mathrm{C}$ and the sun has a low angle of incidence. Because the time of melting is limited, both the rates of ice melt and sediment accumulation are slow. When debris is released on the surface of melting ice, the availability of melt water is one of the major factors determining the nature of the depositional processes.

Since the ice terminus often has a complex form and is difficult to recognize, it is necessary to define the terms used to describe it. Ice edge is used to describe the terminus of a glacier where it is sharp and easily recognizable (Fig. 2a). Ice margin is used to describe an ice terminus where it is not clearly recognizable (Fig. 2b). Within an ice margin an apparent ice edge is often recognizable as an ice cliff beyond which there is often an area of ice-cored moraine, some of which may be under formation (Fig. 2b). The width of the ice-cored moraine or debris-covered glacier is highly variable and can range from tens of metres to several kilometres. If the ice-cored moraine is detached from the glacier, it is described as stagnant. However, because Antarctic glaciers can creep very slowly, it is difficult to be sure if such moraines are really stagnant. The term outer ice edge is used to define the actual glacier terminus where ice movement ceases (Fig. 2b).

Previous studies of the glacial deposits of Vestfold Hills include those of Pickard (1983a, b, 1984) and Fitzsimons (1989). More recently, Lundqvist (1989) has published a series of impressions and observations on the formation of till and glacial land forms. For the present study, three areas of the ice margin in Vestfold Hills were examined in detail (Fig. 1). The first is near Platcha Hut, where the edge of the ice sheet is dome-shaped and marked by prominent gullies and the ice edge is cliffed above a narrow or absent pro-glacial zone of ice-cored ridges (Fig. 3a and b). The second area, near Boulder Hill, is marked by multiple ice cliffs and steep snow-covered ice ramps (Fig. 3c) and a narrow icecored pro-glacial zone with multiple ridges and numerous proglacial lakes. The third area is Flanders Moraine (Fig. 1), which is a large area of slowly creeping debris-covered ice (Fig. 3d). At Flanders Moraine, there are no prominent moraine ridges and the landscape is dominated by flat-topped kames and supraglacial lakes.

\section{FORM AND STRUCTURE OF THE ICE EDGE}

The morphology of the ice edge at Vestfold Hills is highly variable. Most of the ice edge terminates on complex bedrock topography and is obscured by perennial snowdrifts. Where the ice margin is visible, the form ranges from low angle $\left(<5^{\circ}\right)$ ramps, which are frequently covered with extensive supraglacial debris, to $30 \mathrm{~m}$ ice cliffs (Fig. 3).

All exposures at the margins showed that the ice contains relatively low debris concentrations. Measurements of debris concentrations were made by cutting blocks of ice and melting the ice in order to measure the volume and weight of the debris. These measurements showed that debris concentrations ranged from 2 to $8 \%$ by volume. Ice cliffs showed a variety of internal structures that range from relatively undeformed foliation and englacial debris bands (Fig. 4a) to areas of intense deformation which often exhibited recumbent folds and shear structures (Fig. 4b). Such intense deformation is confined to within $10 \mathrm{~m}$ above the base of the glacier and is associated with local deformation at the ice-rock interface or with a general up-glacier dip of the debris bands in the slowly moving terminus ice.

Debris is released from the glacier in two main ways. Where the ice margin is cliffed or steep, debris falls and slides directly from the ice and together with ice fragments forms ice-contact screes (Fig. 4b). The screes appear to be a great deal smaller, less extensive, and less common than they are at the margins of glaciers in the Dry Valleys area of southern Victoria Land (Shaw, 1977a; Chinn, 1985). The bulk of the debris is released where the basal debris zone becomes warped and reaches the surface of the ice and where the ice surface is lowered by ablation to expose the englacial and basal debris zones. Where this occurs, prominent "inner" or "shear" moraines (Bishop, 1957; Weertman, 1961) are formed within the ice margin. These ice-cored moraines form low ridges up to $500 \mathrm{~m}$ inland of the ice margin and are continuous for up to $1.5 \mathrm{~km}$. Beyond and adjacent to the apparent ice edge, larger areas of ice-cored moraine with older inner moraines are common and appear to remain attached to the glacier. The largest of such areas is Flanders Moraine which is about $2.5 \mathrm{~km}^{2}$ in area and reaches $1.6 \mathrm{~km}$ in width (Fig. 3d). 


\section{DEPOSITIONAL PROCESSES ON THE MORAINES}

For the purposes of this paper, till is defined as a sediment that is deposited directly from glacier ice and which has not undergone subsequent disaggregation and re-sedimentation (Lawson, 1979). When tills are mobilized after deposition, they are called re-sedimented or secondary deposits. Lawson $(1979,1981)$ has described a wide variety of secondary deposits in glacial environments including sediment flows and other mass-movement deposits. The dominant sedimentary processes on the moraines in Vestfold Hills involve the re-sedimentation of material initially deposited as till.

All melting and sublimation of ice is confined to the upper surface of the glacier and ice-cored moraines. No basal melt is known. Both the ice-cored moraines and the ice edge appear to consist of "cold" ice that is below $0^{\circ} \mathrm{C}$ or the pressure-melting
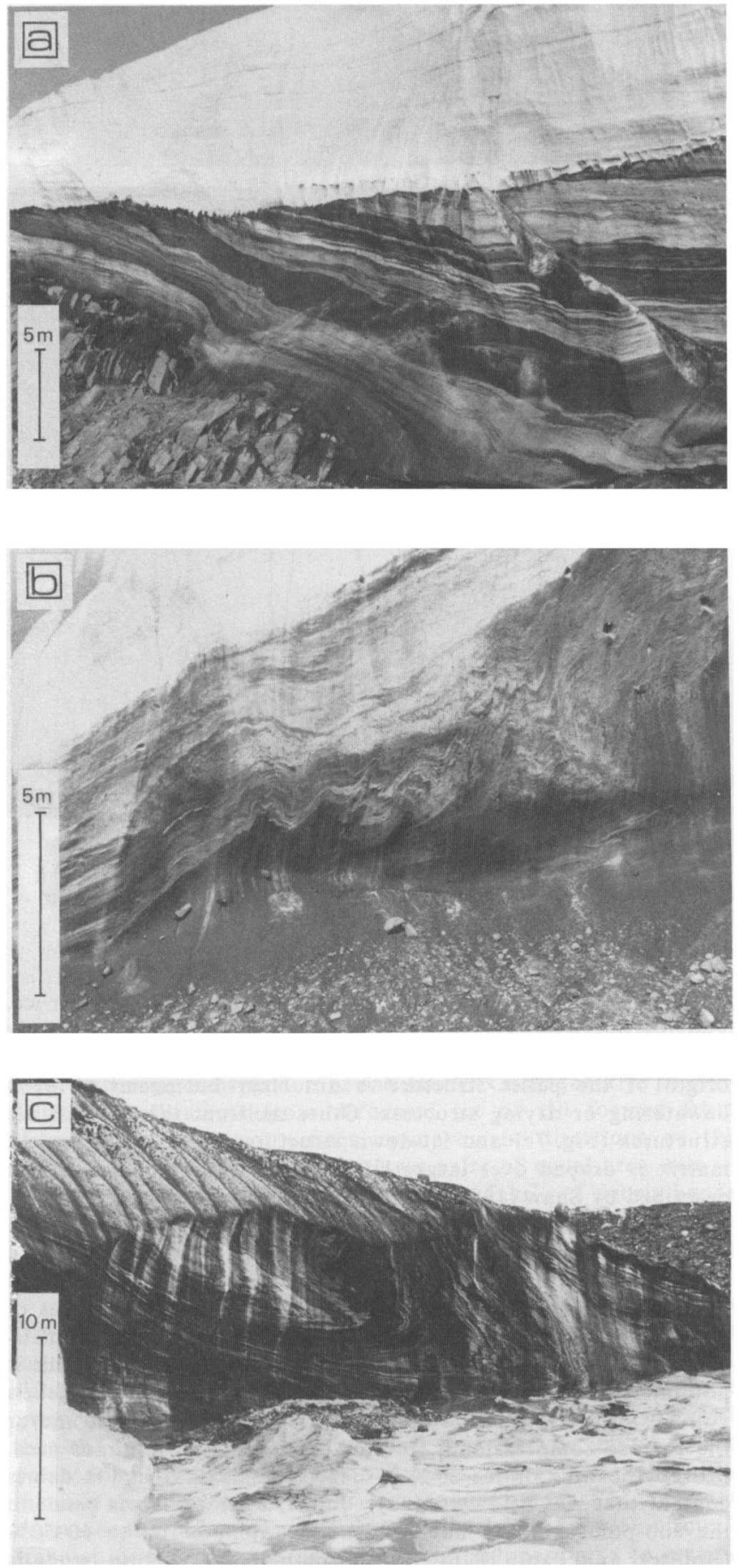

Fig. 4. Structures in the lower debris-rich layer. a. Faulted debris bands flowing over a rock obstruction at Boulder Hill. The overlying "clean" ice appears to have accumulated in the terminal areas as superimposed ice that forms a snow wedge. $b$. Disharmonic folds in basal zone ice in Thule Gully near Platcha. $c$. Folded debris bands exposed in the central part of an ice-cored moraine ridge at Boulder Hill. point. The only tunnels in the moraines are surface melt-water channels that have been roofed by snow. Karstic destruction of the moraines, as described by Healy (1975), does not occur.

Although melting of the ice is most effective when the air temperature is above zero, solar radiation can make a substantial contribution to the ablation of ice-cored moraines. During January 1988, for a period of $4 \mathrm{~d}$ of sub-zero temperatures and cloudy skies, ice melt and melt-water flow ceased. In the following $3 \mathrm{~d}$ when skies were clear but temperature remained below zero, ice began to melt again and melt water began to flow. This melting was almost entirely due to the transfer of radiant energy to sensible heat at the surface of the ice. This process was most effective on steep ice slopes which have a high angle of incidence and receive more radiation than flat surfaces (Chinn, 1987). Slopes that had a thin debris cover melted most rapidly because they had a lower albedo than clean ice. The transfer of solar radiation to sensible heat in the turbid supraglacial lakes is also probably quite significant but it was not possible to assess its importance.

When debris is released on to the ice surface by ablation, it is water-saturated and highly mobile. In this initial phase of ablation, the most frequently occurring deposits are sediment flows and other mass-movement deposits. Tills do not generally form until the debris cover consolidates and ablation rates decrease.

\section{Sediment flows}

The steep slopes, thin debris cover, and high melting rates of the ice-cored moraines in the Platcha and Boulder Hill areas cause the slopes to be unstable and subject to many forms of mass movement. In these situations, the dominant sedimentary processes involve mass movement of saturated sediments and the potential for the preservation of melt-out and sublimation till is limited. Although several types of mass movement of watersaturated sediments occur on the moraines, the most common are sediment flows. Other forms of mass movement include slumps, slides, and falls.

The wide variety of sediment flows that occur in glacial environments has been documented by Boulton (1968) (who called them flow tills) and by Lawson (1979). The main sources of the sediment flows in Vestfold Hills are material that has slumped from small melting ice scarps on the ice-cored moraines (Fig. 5a). The initiation and mobility of sediment flows depends on the slope, the particle size of the debris, and the availability of melt water to saturate the debris, to increase pore-water pressures and to lubricate the ice-sediment interface. When melt water begins to flow in streams, its importance in the dispersal of debris decreases because the turbid water thermally erodes deep channels in the underlying ice and does not erode or transport much debris. Most ice-marginal streams flow into pro-glacial moraine or rockdammed lakes which act as sediment traps and ensure that very little sediment escapes from the ice-marginal area.

The sediment flows have a large variety of types and forms that range in texture from gravelly sand (Fig. 5b) to silty diamictons (Fig. 5b). The surface form of the flows is largely determined by particle size, water content, and slope. Sediment flows with a high water content tended to occur on low-angle slopes and form flat, planar lobes or streams where they were confined (Fig. 5b). On steeper slopes, the flow tended to have a lobate form and have a much lower water content (Fig. $5 \mathrm{c}$ and $\mathrm{d}$ ).

The flow rates of sediment flows observed on the ice-cored moraines in Vestfold Hills were measured by placing a line of painted stones across different parts of the flows and measuring their movement every $24 \mathrm{~h}$. The recorded flow rates are all low and could be referred to as creeps rather than flows (Table I). The reason for the low flow rates is primarily related to the climate of the terminus area. Low temperatures, low relative humidity of the

TABLE I. FLOW RATES OF SEDIMENT FLOWS IN VESTFOLD HILLS

Period of Mean daily
measurement movement

mm

mm

Boulder Hill 1

Boulder Hill 2

Platcha 1

Platcha 2

Flanders 1

Flanders 2

$\begin{array}{rc}9 & 60.2 \\ 7 & 51.6 \\ 6 & 169 \\ 6 & 79.2 \\ 10 & 12.1 \\ 10 & 0\end{array}$

51.6

79.2

0
440

150

930

220

42 

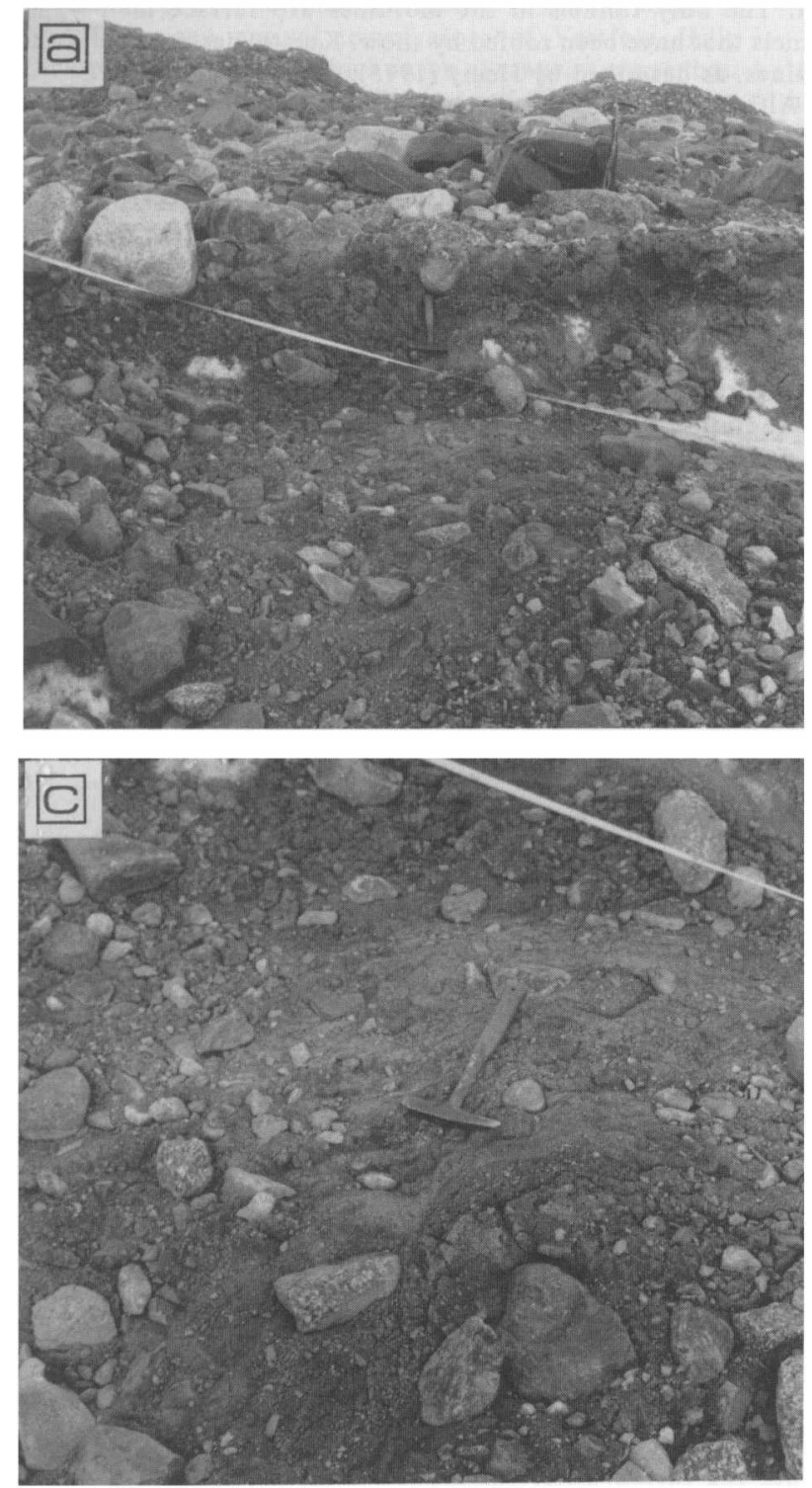
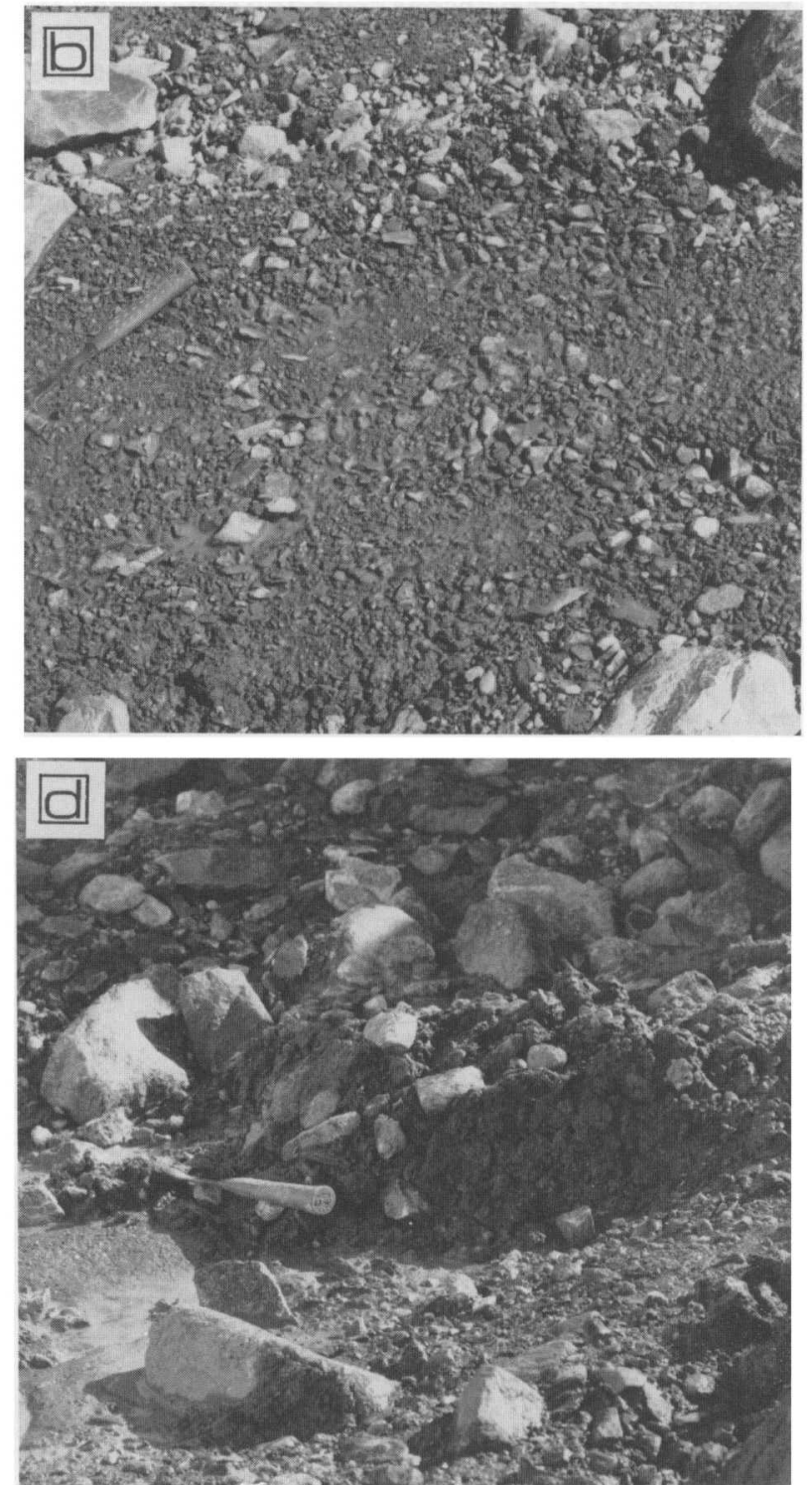

Fig. 5. Sediment flows. a. A retreating ice scarp supplying sediment to a series of flows at Platcha. b. A coarse sandy gravel sediment flow with a surface slope of 58 at Boulder Hill; flowing from right to left. c. Frozen surface of the sediment flow shown in Figure 5a. d. Plug zone of a sediment flow discharging water and depositing a small mud fan at Platcha.

area, and diurnal freezing of the sediment flows result in short daily periods of thaw and saturation of supraglacial debris. Another effect of diurnal freezing and rapid drying of the sediment flows is to produce a series of stacked flows with prominent plug zones which mark the drying or freezing of flows and record individual flow events (Fig. 5d).

Sections through inactive sediment flows show they are massive and similar in appearance to melt-out tills. However, the flows have a characteristic pebble fabric which is fairly consistent (Fig. 6). Most lack a strong preferred orientation and are widely dispersed about the principal eigenvector $\left(V_{1}\right)$, though some clearly have a relatively strong preferred orientation. The stronger preferred orientations are often associated with the less-saturated, slowly moving flows.

As the thickness of supraglacial debris increases, the melting rate of the buried ice decreases and sublimation may become a more important component of total ablation. With the decreased availability of melt water, the supraglacial debris rarely becomes saturated, sediment flows become less common, and the debris cover stabilizes. This tends to occur in the older, outer parts of the low-relief ice-cored moraines such as the outer parts of Flanders Moraine.

\section{Till formation}

Till forms when debris is released on the ice surface by ablation and there is little or no post-depositional movement. These requirements are only met where the slope of the ice is low or the debris being released is under confining conditions and cannot be mobilized.
Figure 7a shows a typical melt-out till resting on glacier ice. The till has a pellet structure where much of the mud matrix formed elongated pellets from 5 to $12 \mathrm{~mm}$ long (Fig. 7b). The origin of the pellet structure is not clear but seems to be a dewatering or drying structure. Other melt-out tills have fissile structures (Fig. 7c) and let-down structures (Fig. 7d) where the matrix is draped over larger clasts in a manner similar to that described by Shaw (1983).

The fabric of disc, blade, and prolate-shaped clasts in the till was measured at several locations. A sample of these is shown in Figure 8. The equal-area plots show a reasonably consistent pattern of a strong unimodal distribution in most exposures of melt-out till. The fabrics are weaker than those described for meltout till by Lawson (1979) and Shaw (1982). The reason for this is not immediately clear but it may be related to the low debris volumes, dispersed nature of the debris in the glacier ice, and/or the intense compressional flow of the ice in the terminus area. Most exposures of ice showed debris bands that had a debris content that was below $10 \%$ by volume, whereas debris bands in the sub-polar glaciers have a debris content of up to $40-50 \%$ (Boulton and Paul, 1976). As the ice matrix of debris bands is removed, the pebbles re-orientate themselves until they are stopped by clast-to-clast contact. When the debris is highly concentrated, there are numerous interparticle contacts and the dispersion of pebble fabric is minimal and usually results in the lowering of the dip of many clasts (Boulton, 1971; Lawson, 1979). In ice with a low, dispersed debris content, the re-orientation of clasts during ablation may significantly affect the fabric orientation and reduce the fabric strength of the till. Intense compres- 
a
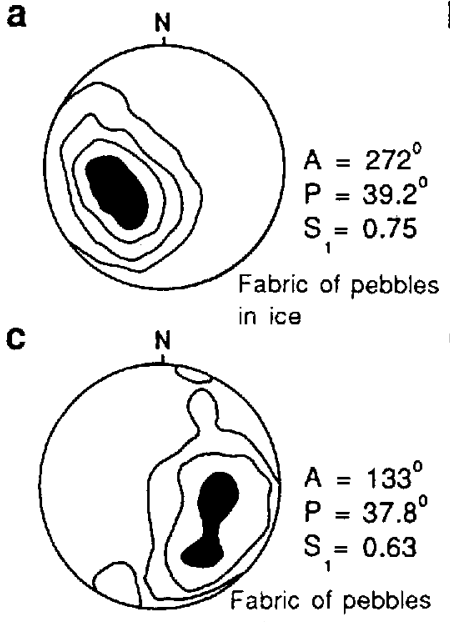
in ice
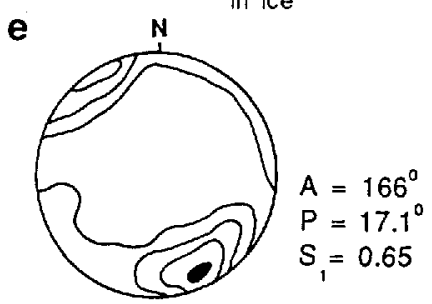

g

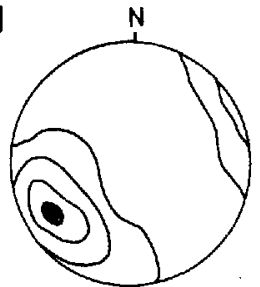

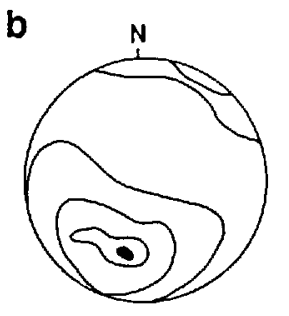

$A=208^{\circ}$

$P=28.3^{\circ}$

$S_{1}=0.64$
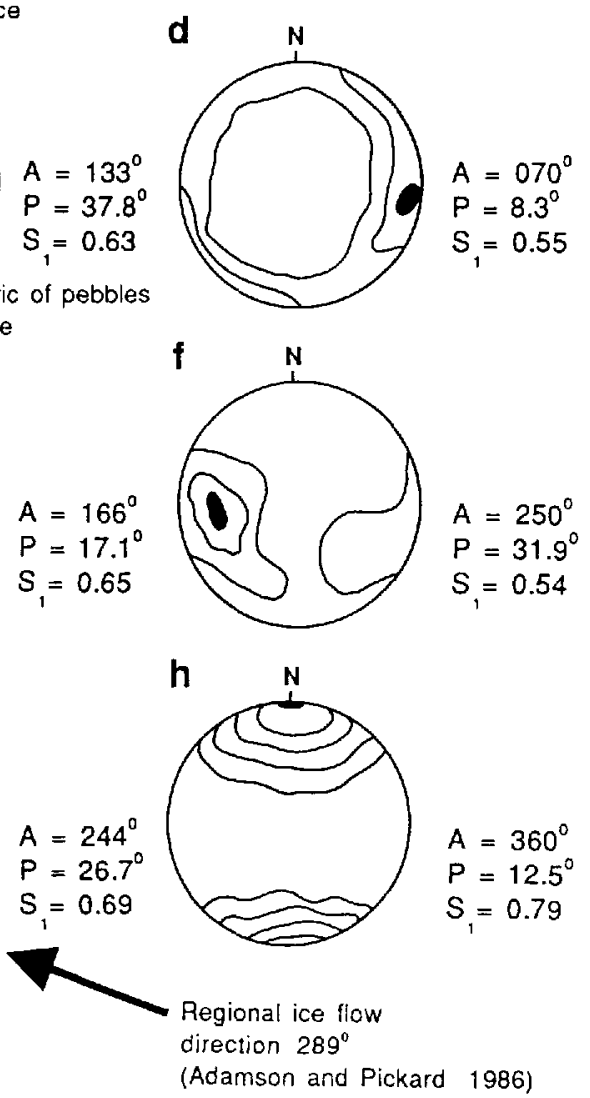

Fig. 6. Pebble fabrics associated with sediment flows. a-c at Platcha; $d-e$ at Boulder Hill; $f$ h at Flanders Moraine. Lower hemisphere equal-area plots contoured by the method of Kamb (1959). The contour interval is two standard deviations. $A$ and $P$ give the trend and plunge of the principal eigenvector $\left(V_{1}\right)$ and $S_{1}$ gives the strength of clustering about $V_{l}$. The arrows indicate flow directions.

sional flow of ice in the terminus area may have a significant effect on pebble fabric because flow compression can result in localized deformation and dispersion of the fabric. Consequently, pebblefabric measurements from deformed ice or till formed from deformed ice may not reflect ice-movement directions or the depositional processes. The first two pairs of equal-area nets in Figure 8 show the difference between the fabric of debris bands and the tills that have formed from their ablation. Both of these show that the strength of the englacial fabric decreases as the till forms.

The thickness of melt-out tills forming on ice-cored moraines is controlled by the depth of the active layer of the permafrost. At present, tills from 10 to $80 \mathrm{~cm}$ in thickness occur with exceptional thicknesses up to $1.2 \mathrm{~m}$. The thicker sequences of melt-out till are frequently associated with lacustrine sediments, which suggests that the formation of some melt-out tills may be linked to the presence of supraglacial ponds and lakes. Supraglacial lakes may increase the thickness of till because the thermal mass of the water depresses the permafrost layer under the lakes. In such circumstances, the thickness of the supraglacial sediment may be greater than would ordinarily form on the surface of the moraine. Where the depth of the permafrost layer is not depressed by the thermal mass of supraglacial lakes, the release of melt-out till is controlled by the thickness of supraglacial debris and the depth of summer thawing (Boulton and Paul, 1976). When the debris thickness equals the depth of summer melting, the remaining ice lies below the permafrost table and can only be removed by sublimation (Shaw, 1977a) or by a climatic amelioration. Consequently, large bodies of stagnant or slowly moving ice such as Flanders Moraine may become semi-permanent features and exist beyond a retreating ice front (Boulton, 1970a, b; Shaw, 1977a) even though they may remain attached to the glacier. Ablation may be reduced to such a small rate that the ice can last for thousands of years. For example, the ice-cored Ross Drift of the Dry Valleys has survived for more than 20000 years (Denton and others, 1985).

Extensive areas of ice-cored moraine such as Flanders Moraine (Fig. 3d) clearly have the potential for the formation of sublimation till, which has been identified on the basis of the preservation of intricate glacier-derived foliation (Shaw, 1977a). Although some tills encountered in Vestfold Hills show evidence of the preservation of foliation, it was not possible to determine whether the till had formed by the process of sublimation because there are no sedimentary structures that are known to be diagnostic of a sublimation origin.

\section{DISCUSSION}

Apart from the occurrence of multiple ice cliffs at Boulder Hill (Fig. 3c), the structure and form of the ice edge at Vestfold Hills appears to resemble that of many polar and sub-polar glaciers and ice sheets. The origin of the supraglacial and pro-glacial icecored moraines ("shear" and "inner" moraines) has been the subject of several studies in Baffin Island, Ellesmere Island, Greenland, Svalbard, and Antarctica (Bishop, 1957; Hollin and Cameron, 1961; Souchez, 1967; Boulton, 1970a; Hooke, 1970, 1973). However, the mechanism by which debris is entrained into the glacier and transported to the surface of the glacier has been the subject of considerable debate and has yet to be clearly established.

Englacial and basal debris zones are brought to the surface of the ice in areas of flow compression that have been related to iceflow deceleration in the terminal area (Boulton, 1970a; Hooke, 1970). Flow deceleration has been related to the grounding of a semi-rigid rheological zone in the upper parts of glaciers (Holdsworth, 1969; Chinn, 1985; Chinn and Dillon, 1987) and to the presence of an outer zone of basal freezing. In Vestfold Hills, the form, structure, and position of the ice-cored moraines can be directly related to the pattern of englacial ice flow and deformation. The flow compression appears to be primarily related to flow deceleration due to obstruction by the slowly moving ice-cored moraines and possibly to the grounding of the semi-rigid rheological zone where the thickness of the ice margin decreases.

The clearest exposure of an ice-cored moraine ridge observed in this study shows evidence of large-scale overfolding (Figs $3 \mathrm{c}$ and 4c). The presence of the folds and lack of thrust faults along the fold limbs or in the hinge suggests that most strain has been accommodated by plastic deformation. The mechanism of shearing where active ice slips over obstructing ice along discrete shear planes (Weertman, 1961) does not seem to be an appropriate explanation for the formation of this moraine and others like it in Vestfold Hills. The formation of such a "shear" moraine at the site of a large fold is similar to part of a model of deformation during the advance of polar glaciers proposed by Chinn (1985) in which moraines formed during a period of intense compression and plastic deformation associated with an ice advance. The present position of the apparent ice edge over $300 \mathrm{~m}$ east of the moraine suggests a recent history of ablation in this part of the ice margin (Fig. 3c). However, because the moraine is still attached to the glacier and may still be creeping very slowly, it is not possible to infer from its position whether the ice margin has been advancing or retreating.

The patterns and processes of debris dispersal in Vestfold Hills can be contrasted with models of sedimentation developed for glaciers with different thermal conditions. Three basal thermal regimes that can be recognized at the margins of modern glaciers are: temperate glaciers which are wet-based and slide over their bed; polar dry-based glaciers which are frozen to their bed and move by internal deformation; and complex, polythermal glaciers where part of the glacier slides over its bed and parts are frozen to the bed (Boulton, 1972, 1975; Boulton and Paul, 1976; Shaw, 1977a; Eyles and others, 1983). The significance of the basal thermal regime for the deposition of debris is that it controls the thickness of the basal debris zone, the position in which the debris is deposited, and the manner in which it is deposited (Boulton, 1970b). The sediments deposited by each of these glacier types are distinctive and have been associated with a diagnostic sediment/ land-form association (Boulton and Paul, 1976; Eyles and others, 1983). However, the basal thermal regime of glaciers is only one of 

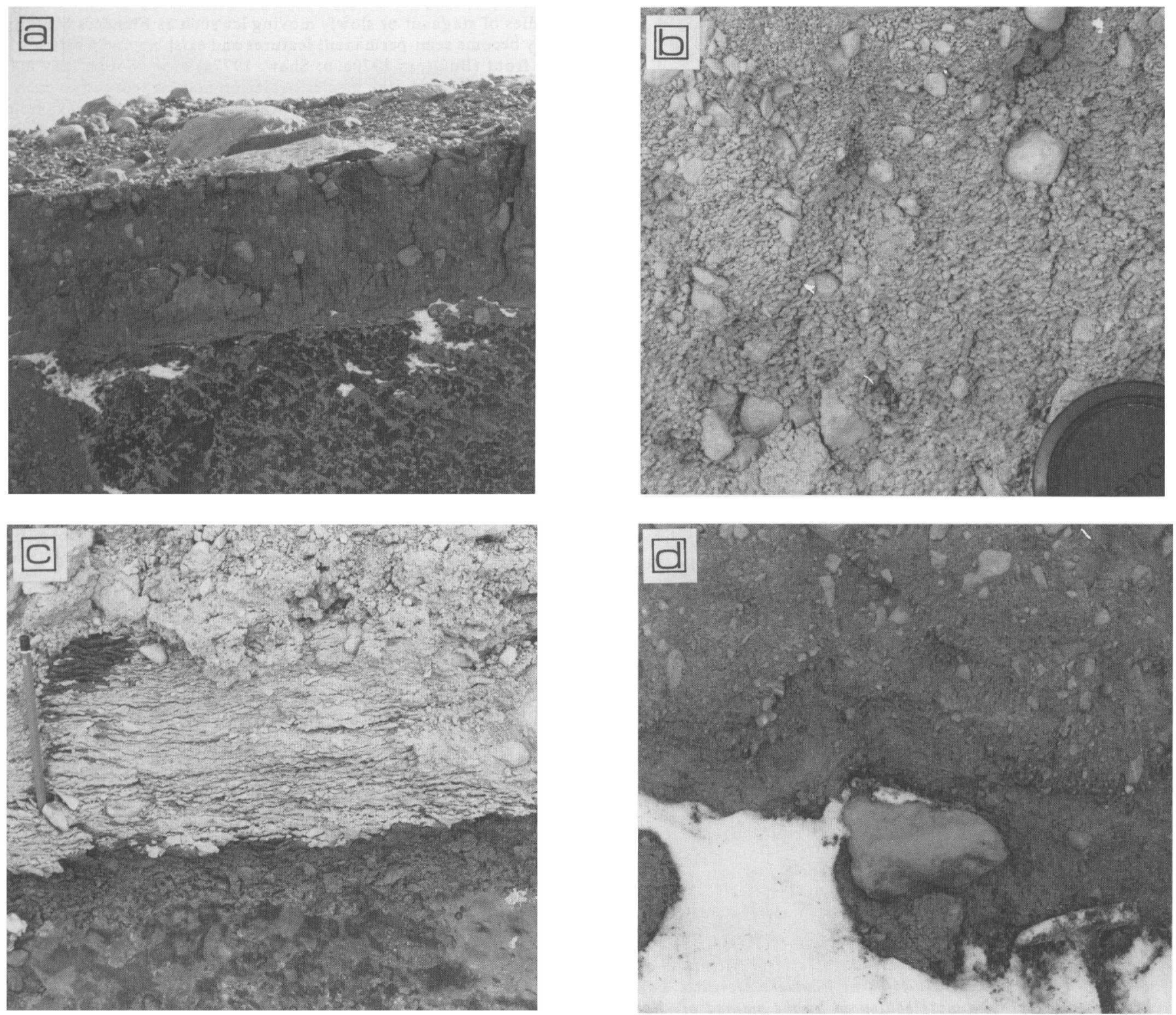

Fig. 7. Structures in till. a. Probable melt-out till resting on ice with a very low debris content at Flanders Moraine. $b$. Pellet structure in melt-out till at Flanders Moraine. c. Horizontal jointing parallel to ice foliation in melt-out till at Flanders Moraine. d. Let-down structure around a cobble in melt-out till at Boulder Hill.

the controls on glacial deposition. An equally important, if not more important, control is the climate of terminus areas because it determines the rate of ablation and the availability of melt water.

The depositional processes that have been observed at the margins of dry-based polar glaciers are largely determined by the low volume of debris in the glaciers, availability of water at the terminus and by in-situ lowering of englacial debris on to the substrate during glacier recession (Shaw, 1977a; Eyles and others, 1983). This type of glacier produces a distinctive depositional sequence that consists of pro-glacial fluvial sediments and sediment flows overlain by poorly attenuated and highly attenuated sublimation till (Shaw, 1977a, b). The tills are deposited by a combination of melt-out and sublimation of basal debris during which the structural properties of the basal debris such as foliation are preserved.

In contrast, polythermal glaciers transport greater volumes of debris which is released on the glacier suface as the debris bands are upwarped in the terminal area. The depositional processes are conditioned by the high availability of melt water which frequently causes the mobilization and redistribution of tills which gives rise to a characteristic supraglacial land form and sediment association (Boulton and Paul, 1976). The main types of deposits that form are melt-out tills, lodgement tills, and a wide variety of secondary deposits including sediment flows.

Vestfold Hills at lat. $68^{\circ} 35^{\prime} \mathrm{S}$. with a mean annual temperature of $-10.2^{\circ} \mathrm{C}$ have a climate that appears to be intermediate between polar arid areas such as the Dry Valleys, at lat. $77^{\circ} 30^{\prime} \mathrm{S}$., with a mean annual temperature of $-19.8^{\circ} \mathrm{C}$ at Vanda (Schwerdtfeger,
1984) and areas with a sub-polar maritime climate such as Svalbard at lat. $78^{\circ} 04^{\prime} \mathrm{N}$., with a mean annual temperature of $-5.2^{\circ} \mathrm{C}$ (Vowinckel and Orvig, 1970). However, the depositional processes and the land-form/sediment association of the icemarginal area of Vestfold Hills closely resemble those of the subpolar glaciers and are quite unlike those described by Shaw $(1977 a, b)$ for polar glaciers that experience an arid climate.

The sub-polar glaciers of Svalbard described by Boulton $(1968,1970 a, b, 1972)$ and Boulton and Paul (1976) have a complex thermal regime, and transport large volumes of englacial debris that can produce up to $8 \mathrm{~m}$ of sediment when the ice melts. These glaciers deposit a supraglacial sediment and land-form association (Boulton and Paul, 1976) that has strong similarities to the glacial deposits that form at the margins of the ice sheet in Vestfold Hills. At Vestfold Hills, most of the englacial debris becomes elevated and is released on the surface of the ice as it is in the glaciers of Svalbard, although the volume of englacial debris in the ice at Vestfold Hills is much lower and produces a sediment thickness of no more than $1 \mathrm{~m}$. The release of this debris on the glacier surface and subsequent melting of the ice leads to the formation of controlled and uncontrolled morainic topography (Boulton, 1968). Controlled topography develops when the elevated debris bands crop out on the glacier surface and form distinctive ridges that are parallel to the glacier margin. The furrows between the ridges become the loci of deposition by sediment flows which tends to perpetuate the ridge-and-furrow topography which undergoes relief reversal as the ice core of the moraines is lost. The development of controlled topography can clearly be seen in 


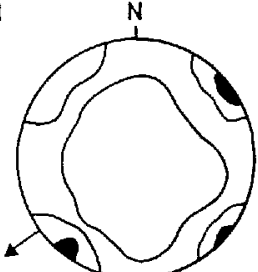

$A=223^{\circ}$
$P=1.6^{\circ}$
$S=0.50$

C
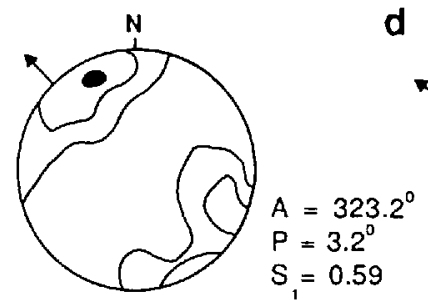

d

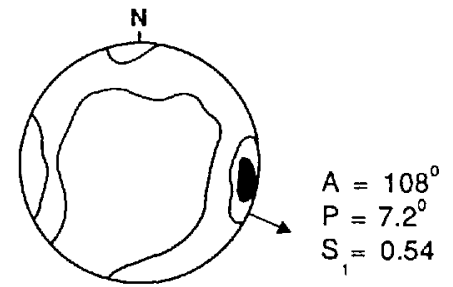

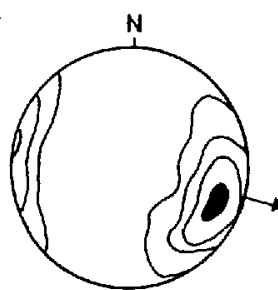

$\mathrm{f}$

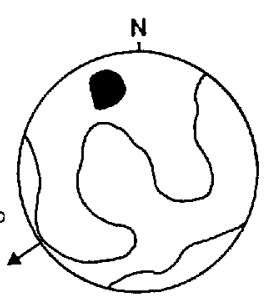
$A=358.2^{\circ}$
$P=22.2^{\circ}$
$S_{1}=0.45$ g

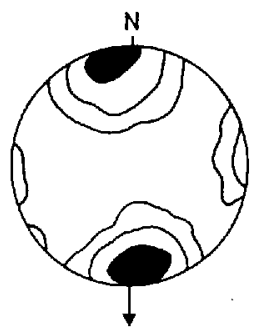

h

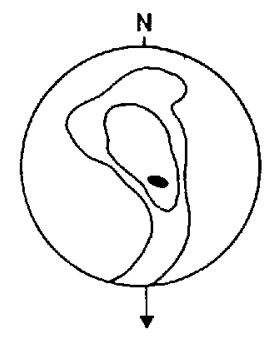

$A=299^{\circ}$ $P=18.4^{\circ}$ $S_{1}=0.77$

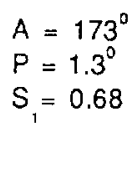

Fig. 8. Pebble fabrics associated with melt-out tills. a-d. Two pairs of pebble fabrics from basal zone ice (left) and from overlying tills (right); $e-f$ at Flanders Moraine; $g-h$ at Boulder Hill, Lower hemisphere equal-area plots contoured by the method of Kamb (1959). Contour interval is two standard deviations. $A$ and $P$ give the trend and plunge of the principal eigenvector $\left(V_{I}\right)$ and $S_{I}$ gives the strength of clustering about $V_{1}$.

Vestfold Hills with the development of ridges parallel to the ice edge (Fig. 3). On Flanders Moraine, the debris in the outer areas of the moraine has been progressively recycled as the ice core has been lost by melting, sublimation, retreat of ice scarps, and thermal erosion by streams and wandering lakes (Pickard, 1983a). This reworking has resulted in the formation of kame topography where several former surfaces of the moraine can be identified. The destruction of the ice core of the kames results in the formation of small flat-topped and dome-shaped residual land forms which have been interpreted as pingos (Pickard, 1983b). However, the form, structure, and surface sedimentary processes on the features, and a consideration of the environmental conditions necessary for pingo growth preclude their origin as pingos (Fitzsimons, 1989).

Uncontrolled morainic topography forms where debris is not concentrated in bands across the glacier surface (Boulton, 1968). An example of the formation of uncontrolled morainic topography is the inner part of Flanders Moraine (Fig. 3d) where the debris bands are near horizontal, which results in a relatively uniform release of debris. The debris becomes concentrated in locally developed hollows and stream channels.

One of the main features of deposition from sub-polar polythermal glaciers is that interstitial ice is lost by melting. The deposits, therefore, do not preserve the fine englacial structures though they often retain englacial fabric (Boulton, 1970a, 1971; Lawson, 1979). The principal sediment types that form at the margins of polythermal sub-polar glaciers are melt-out tills, which form in association with sediment flows, and fluvial deposits which may rest on lodgement till. The dominant glacial deposits of Vestfold Hills are sediment flows and other secondary sediments which form in association with lacustrine and fluvial sediments. Melt-out till only begins to form when the debris cover is consolidated and slows the melting of the debris-rich ice or constrains the newly deposited sediment so that it is not mobilized directly after its release. Basal melt-out tills do not occur because all the moraines are cold and show no evidence of subglacial or englacial melting or drainage. Lodgement tills, which require the base of the ice to be at $0^{\circ} \mathrm{C}$ or pressure-melting point, were only observed as thin smears on some erratic boulders and they do not appear to form near the ice margin at present.

The depositional sequence that forms in arid polar environments consists of a pro-glacial fluvial facies overlain by sediment flows and stratified sediments, poorly attenuated sublimation till, and highly attenuated sublimation till that preserves foliation as sub-horizontal joints (Shaw, 1977a, b). This depositional sequence was not observed in Vestfold Hills where the most commonly encountered depositional sequence consisted of melt-out till and/ or sublimation till with horizontal jointing overlain by massive sediment flows, lacustrine, and fluvial sediments. The main difference in the depositional sequences appears to be linked to the availability of melt water and the role it plays in the mobilization of tills. In Vestfold Hills, sediment flows and other mass-movement deposits form before tills, when the melting rate on the surface of moraines is high and produces melt water which leads to the mobilization of debris when released. Melt-out and sublimation tills are not preserved until the thickness of supraglacial debris is sufficient to insulate the ice and ensure the slow melt and/or sublimation of the debris-rich ice. The accumulation of the supraglacial sediment continues by melt-out until the sediment thickness reaches the maximum depth of summer thaw and the remaining ice lies below the permafrost layer. In Vestfold Hills, the active layer of the permafrost in icemarginal areas ranges from 0.5 to $1.5 \mathrm{~m}$. After this thickness of debris is reached, the ice-cored moraines become stable and the ice can only be removed by sublimation or by thermal erosion by wandering lakes and stream channels.

The extent to which the process of sublimation is important in the ablation of ice-cored moraines and the formation of till has not been established. However, Lundqvist (1989) described sublimation till as the most important type of till in Vestfold Hills, even though he conceded that it is rarely observed. Observations in Vestfold Hills suggest there are major problems in the identification of sublimation till. Shaw (1977a) stated that preservation of intricate englacial structures and horizontal jointing are the principal criteria for the recognition of a sublimation origin. However, observations of well-developed sub-horizontal jointing in till forming over steeply dipping foliated ice (Fig. 7c) suggest that the jointing is a dewatering structure and may not be a reliable indicator of the sublimation process. It is clear, however, that there is potential for sublimation in the extensive areas of glacier ice covered by supraglacial sediments and the absence of intricate englacial structures may not preclude interpretation of deposits as sublimation till. The low debris concentrations of ice in Vestfold Hills may prohibit the formation of the highly attenuated sublimation tills because particle movement during ablation may destroy englacial tectonic structures. The extent to which sublimation is important in the formation of sediments and in the loss of ice from the core of moraines in Vestfold Hills requires closer investigation.

\section{CONCLUSIONS}

Although Vestfold Hills may be an intermediate member of a series of high-latitude climatic landscapes with polar continental and polar maritime as end members, the depositional system does not appear to be of an intermediate type. Both the land system and the sediment associations that form in Vestfold Hills have strong similarities to sub-polar glaciers that have a complex thermal regime. The dominant sedimentary processes in the ice-marginal area of Vestfold Hills involve secondary processes which are activated by a high ratio of summer melt to sublimation. These processes redistribute material released in a supraglacial position and limit the potential for the formation of melt-out till until the supraglacial debris cover is consolidated and melting rates decrease. Together, the evidence from Vestfold Hills suggests that the primary control on the glacial sedimentary processes is the climate of the terminus area and that the thermal regime of the ice is only of secondary importance.

\section{ACKNOWLEDGEMENTS}

I am grateful to $R$. Payne for field assistance and to $\mathrm{Dr} T$. Chinn, Dr D. Gillieson, and Professor J. Shaw for their helpful 
comments on the manuscript. This work was supported by Australian National Antarctic Research Expeditions and an Antarctic Science Advisory Committee grant. Logistical support was provided by the Australian Antarctic Division. I thank P. Ballard for drawing the diagrams and E. Hampson for typing the manuscript.

\section{REFERENCES}

Andrews, J.T. 1975. Glacial systems. North Sciutate, MA, Duxbury Press.

Bishop, B.C. 1957. Shear moraines in the Thule area, northwest Greenland. SIPRE Res. Rep. 17.

Boulton, G.S. 1968. Flow tills and related deposits on some Vestspitsbergen glaciers. J. Glaciol., 7(51), 391-412.

Boulton, G.S. 1970a. On the deposition of subglacial and melt-out tills at the margins of certain Svalbard glaciers. J. Glaciol, $9(56), 231-245$.

Boulton, G.S. 1970b. On the origin and transport of englacial debris in Svalbard glaciers. J. Glaciol., 9(56), 213-229.

Boulton, G.S. 1971. Till genesis and fabric in Svalbard. In Goldthwait, R.P., ed. Till; a symposium. Columbus, $\mathrm{OH}$, Ohio State University Press, 41-72.

Boulton, G.S. 1972. The role of thermal régime in glacial sedimentation. In Price, R.J. and D.E. Sugden, eds. Polar geomorphology. London, Institute of British Geographers, 1-19. (Special Publication 4.)

Boulton, G.S. 1975. Processes and patterns of subglacial sedimentation: a theoretical approach. In Wright, A.E. and F. Moseley, eds. Ice ages: ancient and modern. Liverpool, Seel House Press, 7-42.

Boulton, G.S. 1976. Till - its genesis and diagenesis. U.A.M. Seria Geografia, 12, 65-80.

Boulton, G.S. and M.A. Paul. 1976. The influence of genetic processes on some geotechnical properties of glacial tills. Q.J. Eng. Geol., 9, 159-194.

Burton, H.R. and P.J. Campbell. 1980. The climate of the Vestfold Hills, Davis Station, Antarctica, with a note on its effect on the hydrology of hypersaline Deep Lake. ANARE Sci. Rep., Ser. D, Meteorol.

Chinn, T.J.H. 1985. Structure and equilibrium of the Dry Valley glaciers. N.Z. Antarct. Rec., 6, Special Supplement, 73-88.

Chinn, T.J.H. and A. Dillon. 1987, Observations on a debriscovered polar glacier "Whisky Glacier", James Ross Island, Antarctic Peninsula, Antarctica. J. Glaciol., 33(115), 300-310.

Denton, G.H., M. Stuiver, and K.G. Austin. 1985. Radiocarbon chronology of the last glaciation in McMurdo Sound, Antarctica. Antarct. J. U.S., 20(5), 59-61.

Eyles, N., C.H. Eyles, and A.D. Miall. 1983. Lithofacies types and vertical profile models; an alternative approach to the description of an environmental interpretation of glacial diamict and diamicite sequences. Sedimentology, 39, 393-410.
Fitzsimons, S.J. 1989. Reinterpretation of pingos in Antarctica. Quat. Res., 32(1), 114-116.

Healy, T.R. 1975. Thermokarst - a mechanism of de-icing of icecored moraines. Boreas, 4(1), 19-23.

Holdsworth, G. 1969. Structural glaciology of Meserve Glacier. Antarct. J. U.S., 4(4), 126-128.

Hollin, J.T. and R.L. Cameron. 1961. 1.G.Y. glaciological work at Wilkes Station, Antarctica. J. Glaciol, 3(29), 833-842.

Hooke, R. LeB. 1970 . Morphology of the ice-sheet margin near Thule, Greenland. J. Glaciol., 9(57), 303-324.

Hooke, R. LeB. 1973. Structure and flow in the margin of the Barnes Ice Cap, Baffin Island, N.W.T., Canada. J. Glaciol., 12(66), 423-438.

Kamb, W.B. 1959. Ice petrofabric observations from Blue Glacier, Washington, in relation to theory and experiment. J. Geophys. Res., 64(11), 1891-1909.

Lawson, D.E. 1979. Sedimentological analysis of the western terminus region of the Matanuska Glacier, Alaska. CRREL Rep. 79-9.

Lawson, D.E. 1981. Distinguishing characteristics of diamictons at the margin of the Matanuska Glacier, Alaska. Ann. Glaciol., 2, 78-84.

Lundqvist, J. 1989. Till and glacial landforms in a dry, polar region. $Z$. Geomorphol, , 33(1), 27-41.

Pickard, J. 1983a. Pingos in Antarctica. Quat. Res., 20(1), 105-109.

Pickard, J. 1983b. Surface lowering of ice-cored moraine by wandering lakes. J. Glaciol., 29(102), 338-342.

Pickard, J. 1984. Retreat of ice scarps on an ice-cored moraine, Vestfold Hills, Antarctica. Z. Geomorphol., 28, 443-453.

Schwerdtfeger, W. 1970. The climate of the Antarctic. In Orvig, S., ed. Climates of the polar regions. Amsterdam, etc., Elsevier, 253 355. (World Survey of Climatology, Vol. 14.)

Schwerdtfeger, W. 1984. Weather and climate of the Antarctic. Amsterdam, Elsevier.

Shaw, J. 1977a. Till body morphology and structure related to glacier flow. Boreas, 6(2), 189-201.

Shaw, J. 1977b. Till deposited in arid polar environments. Can. J. Earth Sci., 14(6), 1239-1245.

Shaw, J. 1982. Melt-out till in the Edmonton area, Alberta, Canada. Can. J. Earth Sci., 19(8), 1548-1569.

Shaw, J. 1983. Forms associated wtih melt-out till. In Evenson, E.B., C. Schlüchter, and J. Rabassa, eds. Tills and related deposits. Rotterdam, A.A. Balkema, 3-12.

Souchez, R.A. 1967. The formation of shear moraines: an example from south Victoria Land, Antarctica. J. Glaciol., 6(48), 837. 843.

Vowinckel, E. and S. Orvig. 1970. The climate of the north polar basin. In Orvig, S., ed. Climates of the polar regions. Amsterdam, etc., Elsevier, 129-252. (World Survey of Climatology, Vol. 14.)

Weertman, J. 1961. Mechanism for the formation of inner moraines found near the edge of cold ice caps and ice sheets. J. Glaciol., 3(30), 965-978. 